\title{
Patterns of bleeding in adolescents with severe haemophilia A
}

\author{
A ARONSTAM, S G RAINSFORD, M J PAINTER
}

British Medical fournal, 1979, 1, 469-470

\section{Summary and conclusions}

Eighty-two boys with severe haemophilia A who spent some time at Lord Mayor Treloar College during 1973-7 were studied. All episodes of bleeding that occurred during term time were recorded, along with the number of transfusions. The bleeding frequency among these boys, most of them aged 10-17 years, increased steadily from 8,31 episodes/100 days in 1973 to 12.63 episodes/100 days in 1977. At the same time there was a steady fall in bleeding frequency with age. Altogether $24 \%$ of bleeding episodes were into the elbow joint, $22 \%$ into the knee, and $15 \%$ into the ankle. As the boys grew older the proportion of bleeding episodes in the legs declined and that in the arms increased.

The overall results reflect the fact that special schools now see only the severest cases of haemophilia. The pattern of bleeding during adolescence suggests that concepts of management of arm bleeding need modifying.

\section{Introduction}

The frequency of bleeding in haemophiliacs changes with age. ${ }^{1}$ An important time for these patients may be during the physical strains of adolescence. Teenage haemophiliacs today are likely to be more active than those included in earlier surveys, because modern treatment has increased the physical capabilities of young adolescents. We therefore examined the patterns of bleeding in adolescent haemophiliacs in the hope that it would yield new information which might influence their management.

\section{Patients and methods}

The Lord Mayor Treloar College is a school for handicapped children, about a third of whom are haemophiliacs. We studied 82 boys aged 10-17 years with severe haemophilia who attended the school during 1973-7. All the boys had less than $1 \%$ factor VIII present. Haemophilia was diagnosed on the basis of a classical family history or the presence of normal amounts of factor VIII antigen, or both, and a normal response of platelets to ristocetin. Treatment was

\footnotetext{
Treloar Haemophilia Centre, Lord Mayor Treloar Hospital, Alton, Hampshire

A ARONSTAM, MRCPATH, consultant haematologist and director S G RAINSFORD, MD, FRCP, honorary consultant

M J PAINTER, MB, BS, senior clinical medical officer (present address: Manchester Area Health Authority)
}

by transfusion of cryoprecipitate, National Health Service VIII concentrate, or one of the commercial factor VII preparations.

Seven of the boys had inhibitors to factor VIII. They were excluded from all analyses of bleeding frequency but not from those of the sites of bleeding.

During term time the boys were under continuous medical supervision and we recorded all episodes of bleeding during this time. We had to exclude holidays, when the boys were not under our care.

Bleeding frequency was calculated by recording all episodes that occurred while the boys were under our care and expressing them as the number of bleeding episodes per 100 days. $^{2}$ Bleeding frequency was also analysed according to age. When bleeding occurred simultaneously it was counted as a single episode, while the sites were recorded separately. We did not attempt to distinguish whether bleeding into hands and feet affected joints or soft tissues. The most common sites of bleeding are listed separately while less common sites are grouped together.

\section{Results}

We recorded 4935 bleeding episodes in patients without inhibitors to factor VIII. Altogether 6726 transfusions of factor VIII were given for these episodes-an average of 1.36 transfusions each (table I). The number of bleeding episodes and transfusions rose steadily from 1973 to 1977 , while the number of transfusions per bleeding episode rose from 1.23 in 1974 to 1.43 in 1975 but remained steady thereafter. The number of transfusions per bleeding episode rose to a peak of 1.47 among 14 to 15 year olds.

Bleeding frequencies rose sharply from 8.50 episodes $/ 100$ days in 1975 to 11.58 episodes/100 days in 1976 and again to 12.63 episodes/ 100 days in 1977 (table II). Analysis by age showed a small but steady drop in bleeding frequency from 10.44 episodes/100 days in 10 to 11 year olds to 9.63 episodes/100 days in 16-17 year olds.

Of the total of 5450 bleeding episodes (including those in boys with inhibitors to factor VIII) 1302 were into the elbow joint, 1213 into the knee joint, and 801 into the ankle joint (table III). The effect of age on the distribution of bleeding in the four commonest sites is shown in table IV. There was a steady decline in the incidence of

TABLE I-Numbers of bleeding episodes and transfusions according to year and age

\begin{tabular}{|c|c|c|c|c|}
\hline & $\begin{array}{c}\text { No of } \\
\text { patients studied } \\
\text { in each year }\end{array}$ & $\begin{array}{l}\text { No of } \\
\text { bleeding } \\
\text { episodes }\end{array}$ & $\begin{array}{c}\text { No of } \\
\text { transfusions }\end{array}$ & $\begin{array}{c}\text { No of } \\
\text { transfusions per } \\
\text { bleeding episode }\end{array}$ \\
\hline & \multicolumn{4}{|c|}{ No of episodes and transfusions each year } \\
\hline $\begin{array}{l}1973 \\
1974 \\
1975 \\
1976 \\
1977\end{array}$ & $\begin{array}{l}39 \\
43 \\
49 \\
54 \\
51\end{array}$ & $\begin{array}{r}639 \\
708 \\
948 \\
1249 \\
1391\end{array}$ & $\begin{array}{r}782 \\
873 \\
1359 \\
1781 \\
1931\end{array}$ & $\begin{array}{l}1.22 \\
1.23 \\
1.43 \\
1.43 \\
1.39\end{array}$ \\
\hline \multirow[t]{2}{*}{ Total } & & 4935 & 6726 & $1 \cdot 36$ \\
\hline & \multicolumn{4}{|c|}{ No of episodes and transfusions by age } \\
\hline $\begin{array}{l}10-11 \\
12-13 \\
14-15 \\
16-17\end{array}$ & $\begin{array}{l}38 \\
72 \\
73 \\
41\end{array}$ & $\begin{array}{r}557 \\
1636 \\
1532 \\
839\end{array}$ & $\begin{array}{r}669 \\
2126 \\
2245 \\
1131\end{array}$ & $\begin{array}{l}1 \cdot 20 \\
1 \cdot 30 \\
1 \cdot 47 \\
1 \cdot 35\end{array}$ \\
\hline
\end{tabular}


TABLE II-Bleeding frequency according to year and age

\begin{tabular}{|c|c|c|c|c|}
\hline & Patients & $\begin{array}{c}\text { No of } \\
\text { bleeding episodes }\end{array}$ & $\begin{array}{l}\text { No of } \\
\text { days }\end{array}$ & $\begin{array}{c}\text { No of } \\
\text { episodes } / 100 \text { days }\end{array}$ \\
\hline & \multicolumn{4}{|c|}{ Frequency according to year } \\
\hline \multirow[t]{2}{*}{$\begin{array}{l}1973 \\
1974 \\
1975 \\
1976 \\
1977\end{array}$} & $\begin{array}{l}39 \\
43 \\
49 \\
54 \\
51\end{array}$ & $\begin{array}{r}639 \\
708 \\
948 \\
1249 \\
1391\end{array}$ & $\begin{array}{r}7690 \\
9160 \\
11151 \\
10786 \\
11016\end{array}$ & $\begin{array}{r}8 \cdot 31 \\
7 \cdot 73 \\
8 \cdot 50 \\
11.58 \\
12.63\end{array}$ \\
\hline & \multicolumn{4}{|c|}{ Frequency according to age } \\
\hline $\begin{array}{l}10-11 \\
12-13 \\
14-15 \\
16-17\end{array}$ & $\begin{array}{l}38 \\
72 \\
73 \\
41\end{array}$ & $\begin{array}{r}557 \\
1636 \\
1532 \\
839\end{array}$ & $\begin{array}{r}5335 \\
16070 \\
15579 \\
8714\end{array}$ & $\begin{array}{r}10.44 \\
10.18 \\
9.83 \\
9.63\end{array}$ \\
\hline
\end{tabular}

TABLE III-Commonest sites of bleeding

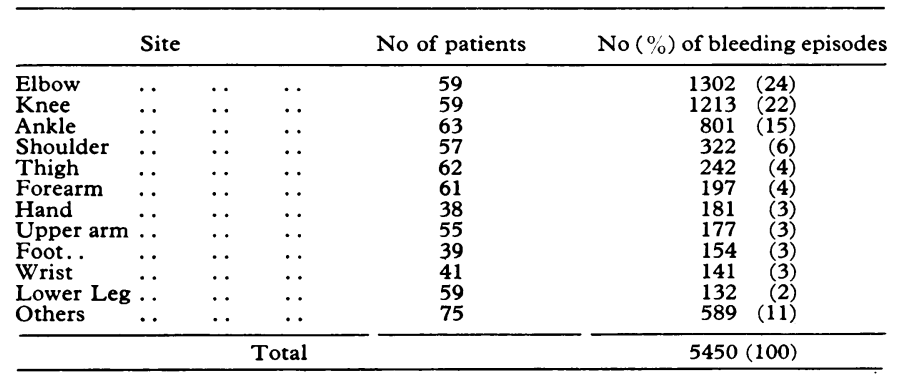

TABLE IV-Percentage of bleeding episodes in major joints at various ages

\begin{tabular}{ccccc}
\hline Age & Knee & Ankle & Elbow & Shoulder \\
\hline $10-11$ & 28 & 20 & 19 & 4 \\
$12-13$ & 24 & 16 & 23 & 6 \\
$14-15$ & 22 & 13 & 26 & 6 \\
$16-17$ & 18 & 11 & 27 & 8
\end{tabular}

knee bleeds from $28 \%$ at 10 to 11 years to $18 \%$ at 16 to 17 years. A similar decline occurred in episodes of bleeding into the ankle. By contrast, episodes of bleeding into the commonest arm sites increased steadily-in the elbow from $19 \%$ at 10 to 11 years to $27 \%$ at 16 to 17 years and in the shoulder from $4 \%$ at 10 to 11 years to $8 \%$ at 16 to 17 years.

An analysis by age of all bleeding episodes in the arms or legs is shown in table V. At the ages studied bleeding at these sites always accounted for about $90 \%$ of all haemophilic bleeds. The incidence of bleeding into the legs, however, fell steadily from $60 \%$ of all episodes at 10 to 11 years to $39 \%$ at 16 to 17 years. By contrast, bleeding episodes in the arm rose steadily from $32 \%$ at 10 to 11 years to $50 \%$ at 16 to 17 years.

TABLE V-Proportion of all bleeding episodes affecting legs and arms

\begin{tabular}{|c|c|c|c|}
\hline & $\begin{array}{c}\text { No }(\%) \text { of bleeds into } \\
\text { leg }\end{array}$ & $\begin{array}{c}\text { No }(\%) \text { of bleeds into } \\
\text { arm }\end{array}$ & Total \\
\hline $\begin{array}{l}10-11 \\
12-13 \\
14-15 \\
16-17\end{array}$ & $\begin{array}{l}315(60) \\
929(52) \\
739(45) \\
346(39)\end{array}$ & $\begin{array}{l}169(32) \\
728(40) \\
752(46) \\
444(50)\end{array}$ & $\begin{array}{r}484 \\
1657 \\
1491 \\
790\end{array}$ \\
\hline
\end{tabular}

\section{Discussion}

We studied boys who were under continuous medical care. Other surveys have been based on attendances at haemophilia centres and have necessarily excluded bleeding episodes which were not reported or were treated elsewhere. We did attempt to document bleeding frequencies while our patients were at home during holidays, but not all haemophilia centres answered our queries, and the data collected were insufficient to compare with those collected at the school.
Over the five years of the survey the number of bleeding episodes more than doubled. Treatment policy remained the same, and so we presume that the haemophiliacs entering the college towards the end of the period were more severely affected. Facilities for home management have improved over the past few years ${ }^{3}$ and so fewer haemophiliacs have to travel long distances, which was previously a major reason for residence at a special school. The schools are probably now seeing only the worst cases, which cannot be managed at home. In support of this only one of the boys present at the college in 1977 had any detectable factor VIII compared with seven in $1973 .^{2}$

The number of transfusions given per bleeding episode in 1973-4 was very similar to the number given at this school in $1970-1 .^{2}$ The increase in 1975 was presumably due to the increased availability of commercial factor VIII. ${ }^{4}$ When prophylaxis is excluded, as in our series, it is apparent that no change in transfusion policy occurred in the years 1975-7.

Other reports show that bleeding frequency declines with advancing age ${ }^{5}$ and our survey of adolescents reflects this. The one exception was the 14- to 15-year age group, which had a higher rate of transfusions per bleeding episode than all other groups. This was due to more severe bleeding, possibly caused by greater activity not yet tempered with greater care.

Our finding that the elbow joint was the commonest site of bleeding differs from those of other surveys. ${ }^{16}$ Our study was confined to adolescence, whereas others have included all age groups. Stuart et al ${ }^{1}$ showed a preponderance of knee bleeds in patients aged 12-21, but the number of episodes studied was less than $5 \%$ of ours. A comparable number of patients was studied by Rizza and Spooner, ${ }^{7}$ but they considered haemophiliacs of all ages and were concerned only with episodes of bleeding treated at home.

Bleeding at 10-14 years occurred more often into the knee joint than into the elbow joint. From 15-17 years the elbow was the commonest site. This difference may be due to patients using their arms more as they become less physically active and to more academic work, or it may simply result from a relative decrease in the use of the legs because of the predominance of leg bleeding in earlier life. However caused, the increase of bleeding into the arm in severely affected adolescent haemophiliacs between the ages of 10 and 17 should warrant special measures to manage and where possible to prevent these bleeds.

In general we believe that when treating arm bleeds in preadolescence or early adolescence it is important to $(a)$ vigorously treat all bleeds; $(b)$ pay scrupulous attention to restoring function; (c) give limited prophylaxis when recurrent bleeds occur, and $(d)$ develop a programme of physical treatment aimed at strengthening the muscles protecting the elbow joint.

This work was supported by a grant from the Sir William Coxen Trust Fund.

\section{References}

${ }^{1}$ Stuart, J, et al, British Medical fournal, 1966, 2, 1624.

2 Rainsford, S G, and Hall, A, British fournal of Haematology, 1973, 24, 539.

3 Jones, P, et al, British Medical fournal, 1978, 1, 1447.

4 Biggs, R, and Spooner, R J D, Lancet, 1978, 1, 1143.

5 Veltkamp, J J, in Handbook of Haemophilia, ed K M Brinkhous, p 371. New York, Elsevier, 1975.

${ }^{6}$ Ramsay, D M, and Khoo, K K, fournal of Clinical Pathology, 1975, 28, 696

${ }^{7}$ Rizza, C R, and Spooner, R J D, British fournal of Haematology, 1977, 37, 53.

(Accepted 27 November 1978)

The official contraindications to whooping-cough vaccine are cerebral problems in the newborn period. If a child has been jittery because of hypocalcaemia, does this by itself count as a contraindication?

Hypocalcaemia in the newborn is not a contraindication to pertussis immunisation. 